development-on research, for instance, in agriculture, education, and health -the maximum results will only be achieved if sociological and linguistic research is carried out at the same time and, as far as possible, especially where 'field-work' is required, in personal co-operation with the representatives of the other sciences. It may, indeed, be taken for granted that the new Advisory Committee will allocate an adequate amount to sociological and linguistic research. For the scientific study of vernacular languages is now fully recognised as essential for the proper development of education in Tropical Africa, and it is notorious that the results of research in other sciences may often be misapplied and the theoretical work prove ineffective in practice unless the sociological factors in the case have also been studied and understood.

\title{
Notes on the Study of African Society.
}

The Study of African Society by Mr. and Mrs. Godfrey Wilson (pp. 20. 6d. 1939) is a valuable addition to the series of Papers published by the RhodesLivingstone Institute. It is designed primarily for the untrained observer. And in the twenty pages of a pamphlet that can be slipped into a pocket it provides him with the essentials of a method of study.

A description of the main types of social grouping is followed by an account of the many-sided nature of social activities and of the need for keeping in view all of these various aspects if the bias of personal interest is to be counteracted and some measure of objectivity achieved. The enumeration of the varieties of grouping that must be investigated might perhaps have closed with a reminder that the character of the social whole will largely depend on the balance between its various component groups. The distribution of authority for instance may tend towards a unitary or towards a pluralistic type of organization and it is perhaps worth pointing out that such tendencies should be summed up in the final picture.

Since stress is laid on the fact that 'the student should have a thorough knowledge of the local vernacular' the Bibliography might have included the Memorandum published by this Institute entitled Practical Suggestions for Learning an African Language in the Field by Dr. I. C. Ward.

But so many things have been packed into such a small compass in this admirable survey that it is churlish to ask for more. An astonishing number of particular examples are included and make a live thing of what, being so compressed, might have been an arid list of general principles. Trained as well as untrained investigators will find this pamphlet a most helpful summary.

Specially welcome is this attempt to cater for the need of European residents in Africa who would willingly observe something of the people among whom they live. Many of them have both time and opportunity. And as 
the authors themselves put it: "Social anthropology, because of its interest, is an ideal hobby; it is also one of the most useful pursuits that a man or woman can engage in, for accurate information upon the changing customs of the African Natives is all too scarce'. It may well be that women-the wives of officials for instance-will be those whose leisure enables them primarily to take up this hobby. If so, what funds of interesting and badly needed information they could amass, among other things, about African women. And in these days of difficult cultural relations every individual is valuable who, by adding to knowledge, increases understanding and mutual tolerance.

Having disclaimed the intention of asking for more, this note is none the less going to end on such a request. The would-be student of society finds himself up against a thousand and one problems of technique. Would it not be possible to expand Section 6 of this pamphlet, "The Technique of Investigation', into a separate memorandum? (Communicated by Miss M. M. Green, M.A., Lecturer at the School of Oriental and African Studies of the University of London.)

\section{Etudes Africaines françaises.}

Les événements du mois de septembre dernier avaient amené la fermeture de certains établissements d'enseignement à Paris; il a paru opportun au gouvernement français de reprendre peu à peu, et dans la mesure du possible, toutes les activités habituelles. L'École Nationale de la France d'Outremer (École Coloniale) a rouvert ses portes avec un effectif restreint. Le Musée de l'Homme, ancien Musée du Trocadéro, qui groupe désormais tous les centres d'études se consacrant aux sciences de l'homme et notamment l'Institut d'Ethnologie, fonctionne de nouveau. Il a mis à la disposition du public et des étudiants ses salles d'exposition, ses salles de travail et sa riche bibliothèque, visitée par de nombreux lecteurs.

L'Institut Français d'Anthropologie, la Société des Africanistes, la Société d'Anthropologie ont repris leurs travaux et leurs réunions ordinaires.

L'Institut Français d'Afrique Noire, un nouvel organisme, fondé depuis 1938, a perdu un certain nombre de ses collaborateurs les plus éminents. Cependant il continue ses diverses activités, avec les moyens dont il dispose. Une circulaire récente signée du Secrétaire Général p. i. annonce que la publication régulière des substantielles Notes Africaines, dont il avait pris l'initiative il y a un an, va se poursuivre. L'Institut avait repris et continue la publication de l'ancien Bulletin du Comité d'Études Historiques et Scientifiques de l'Afrique Occidentale Française, dont le Professeur M. Delafosse avait été le promoteur et l'un des fondateurs en I915. Cette revue va disparaittre pour être remplacée par un autre périodique d'une conception un peu élargie et d'un type légèrement différent. L'Institut poursuivra les séries de 